\title{
Lorne Pierce, Ryerson Press, and The Makers of Canadian Literature Series
}

\author{
Margery Fee
}

Probably every university library in Canada has, scattered through its Canadian Literature section, most of the thirteen blue and gold volumes of Ryerson Press's Makers of Canadian Literature series. ${ }^{1}$ It is just as probable that some of these volumes rarely leave the shelves: who is likely to want a book on Robert Norwood, Arthur Stringer, or Peter McArthur today? Charles G.D. Roberts, Isabella Valancy Crawford, and Stephen Leacock are still widely taught, but the canon has shifted away from William Henry Drummond, Thomas Haliburton, William Kirby, and even John Richardson. Louis Fréchette, François-Xavier Garneau, and Antoine Gérin-Lajoie are all important figures in Quebec history, but none is now claimed as a great poet or novelist. Still, the history of the series is of interest to bibliographers, antiquarian book dealers, and literary historians. Lately, critical attention has turned to such matters as the economics of literary production, the history of the audience's 'reception' of particular works, the formation of national canons, and the description of the institutions connected with any specialized discourse. The history of the Makers of Canadian Literature series touches on all these matters. The series can by no means be described as an unequivocal success: it failed financially, and some of its volumes are uncritical and badly written. Still, other volumes are readable and make good critical sense. And the mere process of preparing the series generated, uncovered, and preserved a great deal of information about Canada's ear'y literary history that, while it remains to be fully exploited, will undoubtedly be useful to both scholars and critics.

Fortunately the series' failure did not dim the enthusiasm of Lorne Pierce for Canadian literature. It is difficult to imagine the fate of Canadian writing without him during the period when Ryerson Press supported many Canadian books which must have lost the firm money. The smallness of the Canadian market and the exigencies of coast to coast distribution still mean losses even for good writers; Pierce, in more difficult times, can be credited with starting many important authors on their publishing careers. No doubt his nationalism interfered occasionally with both his financial and his literary judgement, but even a slightly greater degree of caution might well 
have impelled him to publish very little Canadian literature at all. ${ }^{2}$

Lorne Pierce was a central figure in Canadian publishing between 1922 and I960, the period when he was Book Editor of Ryerson Press. When he arrived at Ryerson in I920, Pierce already seems to have had a very clear personal programme designed to establish Canadian literature - in his own words - 'as a national institution. ${ }^{3}$ By 1924, as part of what he called his 'dream' for Canadian literature, he had donated a medal to the Royal Society of Canada to be awarded for literary achievement, had begun contributing the books and papers of Canadian writers to Queen's University, and had the Makers series well under way. Of these projects he comments in his diary in August I924: 'I have succeeded in having these dreams realized quite early in life. I hope that I shall live to see great fruits. ${ }^{4}$

He was first employed at Ryerson in 1920 as advisor to the Book Steward, Dr. Samuel W. Fallis, who had succeeded William Briggs in I9I 8 . $^{5}$ Pierce was promoted to the newly-created post of Book Editor and Literary Advisor in I922; the Book Editor was 'responsible ... for the literary policy of the Publishing House' and he not only judged manuscripts that were submitted to the firm, but was also expected 'to initiate publications of general importance. ${ }^{6}$ In Briggs' declining years original Canadian trade book publishing at the press had dropped radically, giving place to the easier, less creative, and more profitable agency publication of British and American bestsellers. Both Fallis and Pierce were in essential agreement on the need to improve the House's trade publishing record, especially in the area of Canadian literature. Pierce took his responsibility to initiate publication seriously from the beginning, and was fervent in his desire to improve the situation of literature in Canada. In his retirement speech, An Editor's Creed, he reveals the idealistic quality typical of his nationalism: 'A publisher should be as imaginative and daring as he possibly can. Profits may not always show in the balance sheets, but in the long run they will show in the maturing culture of his country, in the creative forces that are shaping its destiny. ${ }^{8}$

Pierce's nationalism fitted the times: Canadian national feeling was strong just after the First World War, indeed, all through the I920s. Furthermore, Canadian titles had sold well during the war, and publishers were eager to maintain the momentum. ${ }^{9}$ For Pierce, however, the Makers of Canadian Literature series, which he planned to be a forty-volume set of anthologies of the most important Canadian writers, with biographical and critical introductions, was more a contribution to the national spirit than a business venture. In a diary entry headed 'Fall, I922,' Pierce reflects on his conception of the series:

It became imperative to begin somewhere, and with energy. I had to show by some token or other that we were really into it. I had also to invent some way of 
ensuring the writing fraternity [would come?] back to us. I concluded that this series would be the best means. The work needed to be done. The interest in Canadian literature was immense: our national corpus was fast taking shape owing to the war, our nat. soul was taking form and issuing a distinct content just as rapid [sic].

Despite the propitious times, Pierce, inexperienced and ambitious, bit off more than he or the Canadian reading public could chew. The quick failure of the venture, in the period between I923 and I930 when Canadian publishing was on an upswing, ${ }^{10}$ must have taught him a great deal about the limits of the Canadian literary market and of the Canadian 'national spirit.'

Pierce was not alone in his desire to initiate this kind of project, and indeed the pressure of competition may well explain the rush to produce the first volumes. John D. Logan, in response to what must have been a very early exploratory letter concerning the wisdom of the series, writes Pierce enthusiastically, but warns that 'evidently the monograph series "idea" is in the air. ${ }^{11}$ He says that Hugh Eayrs of Macmillan, John Garvin, and McClelland and Stewart were all considering series. ${ }^{12}$ Peter McArthur, in a letter to Pierce dated 7 August 1923, remarks that 'Garvin has sent me the prospectus of his series' and concludes somewhat prophetically 'I am afraid that all this rivalry about recognizing Canadian literature may make some of us look rather ridiculous.' Garvin shared many of Pierce's enthusiasms, which may explain their frequent cooperation where competition might have been expected. ${ }^{13}$ Both Garvin and his wife, Katherine Hale, worked on the Makers series: he completed a manuscript on Charles Mair, while his wife produced the Isabella Valancy Crawford volume. Nonetheless, the threat of competition from this quarter may have worried Pierce. And in 1923 McClelland and Stewart published a Haliburton anthology, Sam Slick, with an introduction by Ray Palmer Baker. ${ }^{14}$

Pierce seems to have spent the time between September 1922 and September 1923 lining up potential authors for the series. A small advertising prospectus fastened into Pierce's diary at the page for 28 September 1923, reveals the ambitious scope of the project from its beginning. This prospectus proposes thirty-five volumes, and lists ten definite titles. ${ }^{15} \mathrm{~A}$ lengthier and more detailed prospectus, probably issued later to promote the series to subscribers, gives a great deal of information about the intended scope of the project. ${ }^{16}$

Each of the published volumes consists of a biography, preceded by a portrait of the 'Maker,' an anthology of the Maker's work, a critical appreciation, a bibliography, and an index. Perhaps because Pierce often assisted with the research, and indeed, provided authors with books and reviews, the bibliographies of secondary sources, which include magazine articles and 
pamphlets, are quite complete. The bibliographies of primary works often include a detailed description of each edition of a work, including translations, and are of a comprehensiveness rare even today. A decision to include summaries of novels in the anthology sections, however, proved unsatisfactory to most reviewers. B.K. Sandwell notes quite correctly that although the anthology method works well for poets and humorists, John Richardson 'gets no chance at all to exercise his strange, romantic, and very long-winded fascination when such a novel as Wacousta is reduced to an eight-page summary. ${ }^{17}$ Long poems were also excluded, or abridged.

Pierce gathered around the project as many eminent names as he could, either as editors, writers, or advisors: the series was not to suffer for lack of literary or social 'cachet.' Victor Morin, the associate editor of the French volumes in the series, was well-known in Quebec as a lawyer, an active member of various historical societies, and president of the Jean-Baptiste Society between I905 and I924. The prospectus contains an introduction in English by Sir Robert Borden, Conservative Prime Minister of Canada between I9I I and I920, and one in French /with an English translation following) by Sir Lomer Gouin, Liberal Premier of Quebec between I905 and I920. Although it would seem odd now to ask politicians to write introductions to a literary series, both Bordon and Gouin carried off the task with aplomb. Borden uses the clichés of Romanticism skillfully, and reveals a knowledge of Ray Palmer Baker's recently published A History of English Canadian Literature to the Confederation (Cambridge, Mass.: Harvard University Press, I920). Gouin, who had worked for 'bonne entente' during the conscription crisis, praises the publisher's 'breadth of mind' for producing works in English and French in the same series. Pierce worked for understanding between French and English Canada all his life, and to include works in French in his series is entirely typical of him, if not of his EnglishCanadian contemporaries.

Although many of the volumes bear no copyright date, information from letters, Pierce's diary, reviews, the prospectus, and the books themselves can be collated to arrive at the following publication dates. Five titles appeared in 1923: Albert Durrant Watson's Robert Norwood appeared first, ${ }^{18}$ then William Renwick Riddell's William Kirby and John Richardson, Peter McArthur's Stephen Leacock, and William Arthur Deacon's Peter McArthur. Katherine Hale's Isabella Valancy Crawford appeared in 1924; John D. Logan's Thomas Chandler Haliburton, John Ford MacDonald's William Henry Drummond, and James Cappon's Charles G.D. Roberts in 1925. Louis Honoré Fréchette by Henri d'Arles (d'Arles is a pseudonym for Henri Beaudé) also appeared in I925, and the two other French volumes, François Xavier Garneau by Gustave Lanctôt and Antoine Gérin-Lajoie by Louvigny de Montigny, either in late 1925 or early I926. The thirteenth title of the 
series, Victor Lauriston's Arthur Stringer, was not brought out until I94 I.

The quality of the series was jeopardized by several obvious factors: the extreme haste with which it was undertaken, the lack of background in Canadian criticism of some of the writers, and Pierce's own lack of critical experience and judgement. His desire to get well-known writers to contribute was sensible and understandable, but this meant that they were often old, imposing, and difficult to criticize. Worse, some had no sympathy with their commissioned subject, while others had too much. Nonetheless, only the first volume to be published, Albert Durrant Watson's Robert Norwood, was obviously bad.

Watson is as difficult to take seriously as a literary critic as Norwood is as a maker of Canadian literature. Watson, a Toronto doctor, poetaster, and best-selling writer on mysticism, was one of Pierce's failings. Pierce and Watson coedited the anthology Our Canadian Literature: Representative Prose and Poetry for Ryerson in 1922, and produced a revised edition in I923. Watson may have been one of Pierce's supporters in developing the Makers project, which might explain how Watson undeservedly became both a series author and a Maker. The bulk of the Canadian reading public was probably not ready for a critic who is capable of writing that the poet has subtle antennae which, trembling outward to the sea and upward to the mountains and the stars, catch new inspirations and discover new wonders, startling the soul and kindling it to the life undying. ${ }^{19}$ The Canadian Forum's reviewer wrote that 'the series was well-nigh drowned in the dreadful molasses of its initial volume. ${ }^{\prime 20}$ The Toronto Mail and Empire warns that the series, if the editor was not vigilant, could 'degenerate into an orgy of log-rolling.' 'Even Robert Norwood,' the reviewer hopes, 'cannot think himself as good as this admirer says he is. ${ }^{21}$

The next four volumes, two by Riddell, one by McArthur, and one by Deacon, are usually reviewed together, and seem to have been published at the same time in I923. William Renwick Riddell was a well-known historian and Ontario judge. Pierce apparently offered him his choice of Gilbert Parker, William Kirby, or John Richardson. In reply, Riddell pleads ignorance of all three, but nonetheless cheerfully offers to do either Kirby or Richardson, or both, provided Pierce will mail him their books. Since he did his writing during a 'cruise in the south' he did not do any original biographical research, but relied heavily on the help of Janet Carnochan, who had known Kirby in Niagara-on-the-Lake, and on Alexander Clark Casselman's detailed biographical introduction to Richardson's War of $1812 .^{22}$ Although the reviewers were generally kind to Riddell, he produced little new or interesting about either writer. ${ }^{23}$

Peter McArthur, a humorist himself, was an obvious choice to write the Leacock volume. Apparently Leacock offered biographical information, but 
did not manage to provide it in time. McArthur wrote him drily, 'As I did not hear from you any further about biographical material I went into the Morgue of the Globe and dug up the material that will be used to write your obituary. ${ }^{24}$ As a result of this excursion, McArthur was able to compile an interesting and amusing biography, but one that contains little original information. The thirty-six-page Appreciation is readable and witty, however, making several points that subsequent critics have also stressed. McArthur comments on Leacock's inability to move a plot - an idea that has become a cliché of Leacock criticism. And later critics would agree with his point that Leacock, although he achieved eminence and respectability, was never 'wholly at ease with the solid citizens and solid institutions of the world. ${ }^{25}$ Although William T. Allison, in a review in the Calgary Herald, states that McArthur should have been confined to the limits of a magazine article, B.K. Sandwell was of the opinion that 'it is a matter for rejoicing that Mr. McArthur lived to write the appreciation of Mr. Leacock. ${ }^{26}$ David Legate, in his Stephen Leacock, I970, states that McArthur 'got closer to the bone than any of the academic commentators. ${ }^{27}$

William Arthur Deacon's contribution to the series, Peter McArthur, has all the advantages and disadvantages of a book written by a friend. Deacon complained to Pierce on 3 May I923, that McArthur 'seems incapable of telling a plain tale of what he has done with his life,' so the biography, although interesting, is not completely authoritative. And Deacon's Appreciation is mistaken in preferring McArthur's poetry to his humorous 'farm pieces' which ran in the Toronto Globe for about fifteen years.

The reviews which considered the merits of the series as a whole generally consider the first five or six volumes to appear. The most damning general review was William T. Allison's in the Calgary Herald, 22 February 1924. Allison was an English professor at the University of Manitoba, where he taught some Canadian Literature, and he also figured extensively on the book pages of several Western newspapers. The review is entitled "You Scratch My Back and I Will Scratch Yours" Seems to Be Motto of Mutual Admiration Society' and subtitled 'Herald Reviewer, in Writing on New Series of Books Issued by Ryerson Press, "Makers of Canadian Literature" Thinks Editor Is Far Too Generous in Trying to Lift into Hall of Fame the Near-Great and the Think-They Are Great - Believes That Many Who Are Written about Will Smile When They Read about Themselves.' Although the efforts of the headline writer also raise a smile, Allison's argument, based not only on the published volumes, but also on the prospectus, is sound. He points out in some detail that many of the critics were close friends or colleagues of their subjects, and argues that the books 'will not be good criticism because friends are in the nature of things inclined to be too indulgent to friends; the living are apt to be too kindly to the living.' Of the 
other reviewers, The Canadian Forum's argues that the series 'implies too large a claim, and the necessity of filling out a book compels the inclusion of inferior pieces among the selections, or of padding in the comment. ${ }^{28}$ No reviewer condemns the series absolutely, but there is an air of 'wait and see' even in the positive reviews.

In December 1923, the Press decided to sell the series by subscription. The decision was not necessarily taken as the result of poor sales; only Norwood had been out for any length of time by then. But some titles in any series are bound to sell better than others, and subscription selling was the common way to market this kind of publication. The prestigious Makers of Canada series produced by Morang between I903 and I9I6 had been sold this way, as had Glasgow, Brook's Canada and Its Provinces (twenty-three volumes) and their Chronicles of Canada (thirty-two volumes); Garvin also planned to use this method to market Master-Works of Canadian Literature. In a letter to William Arthur Deacon on I5 December 1923, Pierce announced this 'radical change in our plans regarding the Makers of Canadian Literature series.'

Authors were to receive instead of royalties, a flat fee of $\$ 500, \$ 400$ on completion, $\$$ IOO on publication. This fee seems extraordinarily high. In 1926, Pierce planned to cut five titles, and in his diary entry for 19 October I925, estimated the saving at $\$ 5,500$. If Pierce was including the author's fee in this figure, as seems likely, the publisher's costs per volume would have been $\$ 600$. If the volumes had been sold at a bookstore at $\$$ I. 50 each, assuming a royalty of Io percent and the bookstore's share at 40 percent, each volume sold would bring the publisher 75 cents, and 800 copies would have to be sold before Ryerson began to make a profit. Subscription sales meant that Ryerson would receive \$ I.50 for each book sold, and would begin making a profit after 733 copies were sold. At first glance, then, the decision to sell by subscription seems sound. But to pay fees rather than royalties was to gamble on high sales. Under the royalty system, the book would have to sell 3,333 copies before the author made $\$ 500$. Under the fee system, the author would be paid no matter how poor the sales. Possibly Pierce was hoping the deluxe edition would subsidize the library edition, since few Canadian titles of this type sold I,00o copies; indeed Ryerson often printed only 250 or 500 copies of literary works. ${ }^{29}$

By comparison, two contemporary McClelland and Stewart contracts show a great deal more conservatism. John D. Logan's and Donald French's contract for Highways of Canadian Literature stated that 'the authors were to pay $\$ 1000$ towards the cost of production and were to receive a royalty of Io percent and 50 cents a copy until the $\$$ I, OoO was re-paid. One thousand copies were printed in December 1924 and another five hundred were printed in May 1928. ${ }^{30}$ Ray Palmer Baker was offered a $\$ 200$ advance and 5 
cents a copy for his Sam Slick. Pierce's offer of \$500 was a large incentive to write such a short work: authors were asked to write biographies of 2,500 words, and appreciations of I0,000 words; they were being paid 4 cents a word. Much of each volume was taken up by anthology - often material for which the 'Maker' would have to be paid. Pierce himself was only earning $\$ 3,000$ a year, and Deacon was still paying reviewers for the Toronto Globe a cent a word in 1946. ${ }^{31}$ Perhaps Pierce felt that the more important writers would not work for less, but since many wrote for far less or nothing quite regularly, he seems to have made a mistake in judgement. Ryerson was clearly doomed to lose money on the series from the start, even if it had sold quite well. Just as clearly, some authors did not give value for money since Pierce did a lot more work than the average editor. Pierce certainly did not find the financial end of the production easy; on the last day of r924 he wrote in his diary that he hoped 'time will obliterate memories of financial dealings with D.C. Scott, Pelham Edgar, R.J.C. Stead, Judge Riddell, J.D. Logan, etc.'

After the series was put on a subscription basis, Pierce lost no time in appointing Thomas Guthrie Marquis to the task of promoting and selling the series to his many contacts in the field of Canadian literature. ${ }^{32}$ Aggressive promotion is the key to subscription sales, as Pierce well knew. In his diary entry for 20 June I924, Pierce was enthusiastic about Marquis: 'He knows more about Can. Lit. than any man in Canada.' By March I925, the series was still not selling; Pierce had finished his work on Parker and confided to his diary 'I have to file it away as I can see no immediate prospect of any others going to press until the sales start up.' In May the final blow fell; Pierce records on the third that Marquis was in Ottawa during Parliamentary Committee Hearings on copyright earlier in the year. ${ }^{33}$ Somehow Marquis involved Ryerson in the committee's report without Fallis' permission. Reproved, he resigned. Pierce was furious that Fallis had jeopardized the future of the series, but could not persuade Marquis to return. By May 24, Pierce had given up hope that any more of the series would be published, as he wrote in his diary that he was hoping that his book on Parker would be 'taken by his [Parker's] publishers and produced abroad.' In October there was one last flurry of activity. Pierce met with Morin to arrange promotion for the French series: François Xavier Garneau and Antoine Gérin-Lajoie were published shortly after. In March I926, Pierce apparently asked Marquis to return, again without success; the letterhead Marquis used in his correspondence revealed that he was working for another subscription series, The Makers of Canada. ${ }^{34}$ Despondently, Pierce concluded his diary entry for 22 March 1926, 'We are letting the Makers rot and not a move is being made.'

Hopes were still high, however, when Katherine Hale's Isabella Valancy 
Crawford was published in I924. The volume was generally well received, although the Canadian Forum said Hale was 'inclined to sob somewhat. ${ }^{35}$ Perhaps Hale can be excused, since Crawford, whose short life was burdened by chronic illness and poverty, genuinely deserved pity. Despite her occasional lapse into sentimentality, Hale makes several trenchant comments about the difficulties of a poet who is not only a colonial, but also a woman. Hale also showed more initiative than any of the other critics, interviewing those who had known Crawford and unearthing manuscript material now at Queen's.

Pierce turned very early to John $\mathrm{D}$. Logan not only to get advice about the series, but also to ask him to write on two Maritime writers - Thomas Chandler Haliburton and Joseph Howe. Letters exchanged in September I922 reveal Logan's familiarity with the plans of McClelland and Stewart, a familiarity that argues he might have already started writing his and Donald French's Highways of Canadian Literature, which appeared in 1924. The chapter on Haliburton in Highways and the Makers volume share strong resemblances, often word-for-word repetitions. The Makers Haliburton does show the improvement of revision either by Logan, or, more likely, by Pierce's editorial hand, since Pierce refused to let Logan write the Howe volume as previously agreed, claiming that he 'practically rewrote' Haliburton 'from beginning to end. ${ }^{36}$ Despite this protest, a manuscript by Logan on Howe is in the Queen's collection, so Logan must have submitted it nonetheless. Logan seems to have been under almost constant financial pressure during these years; Pierce, probably alarmed that he was seeing no manuscript on Haliburton for his advances, finally put Logan on a kind of piece work system. ${ }^{37}$ Logan's normally redundant and italic-studded style, although singularly chastened, is still in evidence in this Makers volume, but his argument is more detailed, and better defended with quotations. The reviews of this volume were quite favorable. ${ }^{38}$ Richard A. Davies reprinted the Appreciation in a collection On Thomas Haliburton in 1979, noting that Logan 'read widely' to prepare the work. ${ }^{39}$

John Ford MacDonald, who wrote William Henry Drummond, was an English professor at Queen's, and later at Toronto. His Appreciation is devoted to proving the superiority of the dialect 'habitant' poems over Drummond's poems in Irish dialect or in standard English. MacDonald uses his personal experiences teaching English in lumber camps as part of the Reading Camp Movement (later Frontier College) to argue that the dialect used in the 'habitant' poems is accurately transcribed from real speech. He makes the helpful point that Drummond, 'like Browning, ... needed the spiritual medium of another character to voice what lay in his deeper consciousness' and shows that several experiences in these 'habitant' poems are closely related to Drummond's personal experiences. ${ }^{40}$ 
James Cappon, who produced the Charles G.D. Roberts volume in the Makers series, was partly responsible, in a negative way, for Pierce's devotion to Canadian literature. Pierce, in Cappon's senior English class at Queen's in I9I2, had asked Cappon whether he thought there was any great Canadian literature: Cappon answered by reciting part of Robert Service's 'The Ballad of Blasphemous Bill' with its refrain of 'It didn't matter a damn. ${ }^{41}$ Although Pierce clearly forgave him, there are frequent references in Pierce's correspondence to the failure of foreign professors to appreciate Canadian literature and to what he calls the patronizing elegance of the Oxonian heads of English Depts. ${ }^{42}$ Cappon (who had an M.A. from Glasgow, it should be said) had been known as a Roberts critic since Briggs' I905 publication of his monograph Charles G.D. Roberts and the Influence of His Times. Pierce noted in his diary on 9 November 1923, that he had agreed to do the biographical section for Cappon, and in an entry for 2 I August 1924, he commented that it took weeks to gather the biographical material. Some time in February 1925, Pierce made Roberts' acquaintance, and found the poet a disappointment. In his diary for I9 September 1925, Pierce writes that he found Roberts 'fleshy, 'weak,' and 'profligate.' Perhaps to reflect his disillusionment without alienating Roberts as a future Ryerson author, Pierce quotes in his biographical section from an account of Roberts' life solicited from Robert Norwood. Norwood, a former student of Roberts, said the poet 'never would take the ethical world seriously. ${ }^{43}$ The biographical section was sent to Roberts' son Lloyd for comment; he replied on 29 December I923, that 'Folks might wonder that you have given so much time to an author who appears to show so little true greatness.... The eulogy imposed upon our minor writers might cause restrained criticism to be misunderstood.' Lloyd Roberts was right in wondering whether such rigour was consistent; in the context of Watson's sticky praise of Norwood, and Hale's hagiography of Crawford, Roberts is done an injustice.

Cappon's Appreciation bears a great deal of resemblance to his earlier Charles G.D. Roberts and the Influence of His Times; he frequently closely paraphrases himself, quotes many of the same excerpts from Roberts in both, and, despite the twenty-year interval between the publication of the two books, devotes almost no attention to the works Roberts wrote after I903, when The Book of the Rose was published. Although Roberts published no more poetry until I9I9, he did produce thirty-six books of fiction, mostly his famous animal stories, to which Cappon devotes only a little over two disparaging pages. The four pages that Pierce gives to them in the biographical section are far more helpful and specific. William Arthur Deacon in Saturday Night, June I925, waxes slightly sarcastic about the study's gaps, and points out that the exclusion of any animal story from the anthology is 'a serious blemish. ${ }^{44}$ The perceptive (or in-the-know) Deacon also 
points to various discrepancies between the Biography and the Appreciation; Pierce had refused to sign the former, although Cappon had asked him to (letters, 30 May and 2 I August I925).

The thirteenth title of the series, Arthur Stringer, by Victor Lauriston, a journalist in Chatham, Ontario, was not brought out until I94I. Stringer's American publishers, Bobbs-Merrill, agreed to co-publish this volume. Pierce had hoped in vain that this kind of cooperation from writers' foreign publishers would underwrite the costs of some of the earlier volumes too. Grace Blackburn, according to the Allison review, a 'newspaper friend' of Stringer's, had completed a manuscript on Stringer for the series in I924, but it was never published. It had been forwarded to Stringer for comment; he wrote to Pierce on 30 May I924, that Blackburn's comment on the 'Irish Poems' was a 'wee bit harsh.' Perhaps Stringer's complaint had something to do with the failure of the Blackburn manuscript to make it into print.

Certainly Pierce was sensitive to what the 'Makers' and their families thought, and was not above asking authors to rewrite their work to fit his concept of what the series was supposed to do for Canadian literature. A 'Maker' of Canadian literature could not be labelled 'mediocre' too often without leading to the kind of comment Lloyd Roberts feared would be made about the Charles G.D. Roberts volume. Although Sir Andrew Macphail's 'Norman Duncan' was never published, his correspondence with Lorne Pierce concerning his work reveals a good deal about the kinds of pressure Pierce put on his writers. Macphail wrote Pierce on 9 November 1923 : 'Norman Duncan has falsified the situation in Labrador; he has grave defects of style. Do you, for example, want these things referred to - Do you want a judgement of his work - or mere eulogy, as Watson has done for Norwood.' Macphail may well have talked to Dr. Grenfell, the supposed model for Duncan's Dr. Luke of Labrador, as he proposed, and did talk to Duncan's brother in order to form his judgement. When the manuscript arrived, Pierce wrote Macphail on 8 February I924, somewhat unhappily:

Here we have an author, granted a MAKER, and yet, upon laying down your book, the unanimous verdict would be that the man ought to be consigned to oblivion. That may be true regarding the majority of his books; but some of his books deserve at least a temporary immortality. Could you not re-cast part of your manuscript, - not to mention the criticism - which criticism is due - but to gather, if you can, the salient features of his strength.... As it stands now, whatever mention you make of his virtues is so embedded in the fiercest kind of criticism that the whole work defeats our purpose.

Macphail, lamb-like, rewrote. He forwarded his revision to Pierce on 26 February I924: 'the book is now exactly as you want it to be. I have written 
an introduction of praise of the stories you reprint. I have mitigated all criticism without sophisticating the truth.' In a postscript he offers to modify the text further, if Pierce wishes.

Of the forty volumes described in the body of the final prospectus, six are on general subjects. Marius Barbeau was to write 'Literary Backgrounds: Indian,' Ray Palmer Baker 'Literary Backgrounds: The Maritime Provinces,' William Stewart Wallace, 'Literary Backgrounds: The Lakes,' Paul A.W. Wallace, 'Literary Backgrounds: The West,' and Victor Morin, 'Literary Backgrounds: French-Canadian.' A 'Dictionary of Canadian Literature,' to be completed by Lorne Pierce, Victor Morin, and Thomas Guthrie Marquis was to give an 'account of every writer of importance from the first settlement of Canada to the year I924.' Barbeau's contribution was completed 9 August 1924, according to Pierce's diary, and is now with Barbeau's papers in the Canadian Centre for Folk Culture Studies Archives at the National Museum of Man in Ottawa. Baker reports completion to Pierce in a letter dated I December I928, and the manuscript is in the Queen's University collection. I have been unable to trace any other completed manuscripts, and none of these surveys was ever published.

The remaining thirty-four books were to deal with individual writers. Many more titles than the thirteen actually published were completed and paid for. Typescripts of some of these are in the Douglas Library at Queen's University, Kingston, Ontario. It can be difficult to decide whether a particular typescript was in fact intended for the Makers series, since typescripts are often undated, and sometimes have no author's name on them. Evidence in Pierce's diaries and letters, and in the prospectus, however, confirms most of the doubtful cases. Grace Blackburn's 'Arthur Stringer' is the only manuscript that these sources record as definitely completed that is not at Queen's. Finished and at Queen's are Richard Albert Wilson's 'George Frederick Cameron,' Robert Stead's 'Ralph Connor,' Andrew Macphail's 'Norman Duncan,' Thomas O'Hagan's 'Dean Harris,' Edmund Kemper Broadus' 'Charles Heavysege,' John D. Logan's 'Joseph Howe,' Ethel T. Raymond's 'E. Pauline Johnson,' Duncan Campbell Scott's 'Archibald Lampman,' John W. Garvin's 'Charles Mair,' and Pierce's 'Gilbert Parker' and 'The Strickland Sisters.' (Heavysege and Mair were to make up one volume.) Pelham Edgar's 'Duncan Campbell Scott' is both at Queen's and in the Edgar Papers at the E.J. Pratt Library at Victoria College, University of Toronto. Some of the others may also have been completed, and might be found with their authors' papers. According to the prospectus, Thomas Guthrie Marquis had agreed to write about William Wilfred Campbell, Rufus H. Hathaway about Bliss Carman, Lawrence J. Burpee about James DeMille, Garnet Gladwin Sedgewick about Joseph Howe, Pelham Edgar about Marjorie Pickthall, Arthur L. Phelps about Robert Service, and Mar- 
garet Lawrence about Albert Durrant Watson. Of the French titles, Aegidius Fauteux had agreed to write about Philippe Aubert de Gaspé, Pierre Dupuy about Octave Crémazie, Seraphin Marion about Henri Casgrain, and Camille Roy about Etienne Parent. Both Dupuy's and Marion's contributions are in the Queen's collection. These ghostly titles can be seen as a I920s canon of Canadian literature. Several of the proposed authors were professors at various universities across Canada: Wilson at Saskatchewan; Sedgewick at the University of British Columbia; Phelps at Wesley College, Winnipeg; Edgar at the University of Toronto; and Roy at Laval. Neither Sedgewick nor Wilson had ever written much about Canadian literature; the series may have had the merit of turning their thoughts in its direction.

To sum up: out of forty proposed titles, twenty-eight were definitely written before the end of 1926; only thirteen were ever published. Indeed, the thirteenth volume, appearing in I94 I, was clearly an afterthought. The project, started by Pierce with so much hope, foundered quickly.

Dating the twelve volumes that appeared in the I920s, as mentioned earlier, is difficult, because in most cases there is no copyright date on the books. ${ }^{45}$ And two usually reliable sources, Reginald Eyre Watters' A Checklist of Canadian Literature and William Stewart Wallace's The Ryerson Imprint, give information that does not accord with the dates of reviews or with Pierce's correspondence and diaries. ${ }^{46}$ Wallace gives I923, correctly, as the publication date for Robert Norwood, William Kirby, John Richardson, and Stephen Leacock. However he gives 1924 as the publication date for Peter McArthur which appeared in I923. Watters correctly gives I923 as the publication date for the first five volumes to appear. But Katherine Hale's Isabella Valancy Crawford, which both he and Wallace say was published in I923, seems from the evidence to have been published in I924. Hale's volume does not appear in any review I have been able to find before I 7 May I924. Further, the decision to sell the series by subscription was not made until early December I923. Hale wrote Pierce on 24 April I924, protesting the decision, apparently made at the same time as the subscription decision, to halt the distribution of review copies. Hale writes: 'When one works slowly, trying honestly to avoid "easy" work, it is rather a tragedy to have a book appear unknown to any but the persons who happen to subscribe for the series.... Could not at least half a dozen copies be sent to the larger papers? It is at least a refutation of the "You scratch my back" legend!' That Hale admits she has been slow, and appears to have heard of the Allison review, are two additional points in favour of the later publication date.

The remaining three volumes in English appear to have been published in I 925 from evidence in the correspondence and since the first review I have found of any of them is dated May 1925. Both Wallace and Watters state incorrectly that Logan's Thomas Chandler Haliburton and MacDonald's 
William Henry Drummond appeared in I923; both give the correct publication date, 1925, for Cappon's Charles G.D. Roberts. Pierce writes in his diary on ro December I924, that 'The first ten vols. of the Makers are being rushed through and are going to look splendid.' He says in a letter to Deacon on 23 January 1925, that ten will be off the press by the end of that month. The figure ten is somewhat cryptic, since only nine English volumes were published in the I920s. Possibly he is referring to a set which would include the six previously published volumes, the three remaining English volumes on Haliburton, Drummond, and Roberts, and possibly Henri d'Arles' Louis Honoré Fréchette, the first of the French titles to appear. Or, since Duncan Campbell Scott's volume on Archibald Lampman was typeset, but never published, it might have been the tenth volume Pierce referred to. (The typeset version is in the Queen's collection.)

Of the French series, only three volumes appeared, all of them most likely in 1925: Henri d'Arles' Louis Honoré Fréchette, Gustave Lanctôt's François Xavier Garneau, and Louvigny de Montigny's Antoine GérinLajoie. Pierce's diary for 6 October 1925 , reveals that the Garneau volume was then being set in type, and that 'Gérin-Lajoie will probably be next.' Gustave Lanctôt's book on Garneau was republished with very little revision in 1946, under the title Garneau: historien nationale with Fides in Montreal, and René Dionne frequently quotes de Montigny in the former's Antoine Gérin-Lajoie: homme de lettres published by Editions Naaman of Sherbrooke in 1978 , so both works seem to have stood the test of time.

That the Makers series failed because of poor sales should not be taken as evidence that it was especially badly done. Books like these sold slowly, and Ryerson appears to have over-extended itself on the series from the beginning. For a series that aimed at a general audience and had few pretensions to the scholarly, the quality was high. Yet with the living authors, despite the stern handling that Roberts received, there was bound to be a problem if the series had continued. Allison was right. Authors and their friends and relatives were closely consulted during the writing of these books, and Pierce's general desire to promote Canadian literature, to attract writers to Ryerson, and to make co-publishing arrangements with the American and English publishers of the series' most popular subjects meant that negative comments, however just, would not pass easily.

To judge the series solely on its critical quality, however, is to ignore its wider impact. No literature, however great, can survive without the apparatus of reference books, library and archival collections, journals, reviews, university courses, literary societies, literary prizes, publishers, bookstores, and readers that provide the writer with a critical response, an audience, and an income. A mediocre literature can only be improved by the existence of such support, despite the common romantic fiction that even 
genius can (and even should) survive the most rigorous neglect. Pierce clearly intended that the series, with its well-known authors and handsome bindings, would impress readers into taking Canadian literature more seriously. Of course, this impact is impossible to measure. But the vast amount of unpublished material associated with the project is certainly valuable for contemporary and future students of Canadian literature. ${ }^{47}$ The material consists of Pierce's correspondence, the manuscripts intended for publication, which often contain biographical information procured from those who knew the authors personally, and the papers collected by series authors or Pierce. Pierce also collected many rare books for Queen's, many of them by or about authors in the series. Much of this information would certainly have been lost if it had not been for the Makers project.

No doubt Pierce's most important contribution to Canadian literature was the publishing support he gave to Canadian writers, but the collecting of the manuscripts and books which he began donating to Queen's in I924 shows unusual farsightedness. Few of his contemporaries realized the value of personal papers, but Pierce wrote almost exultantly in his diary in August I924: 'I am fortunate to be living when I am. In a few years most of our historic litteratti [sic] will have gone and the personalia will be increasingly harder to secure.' Of his publishing activities, a year later, he wrote in the diary 'I want the strongest list in Canada, for while the other Depts. are building up for today, I feel that I am building for the future.' And - even when allowances are made for youthful overstatement - he was.

NOTES

The Lorne Pierce Papers are located in the Douglas Library, Queen's University, Kingston, Ontario, Canada. A catalogue of this collection is available on microfiche from the Douglas Library.

I would be grateful to receive any information concerning the Makers of Canadian Literature series, especially the whereabouts of manuscripts produced for it which are not in the Queen's University collection. I thank H. Pearson Gundy for his permission to use Pierce's manuscript material, and Anthony S. Edwards, University of Victoria, for his comments on an earlier version of this paper.

I According to a bibliography prepared by Frank Flemingdon (Lorne Pierce Papers, box 42 ), the twelve titles first published were issued in two editions: the Library edition was produced in blue cloth, gold-stamped on the spine and facsimile signature blind-stamped on the front cover, $65 / 8^{\prime \prime} \times 4^{1 / 4^{\prime \prime}}$; the Fréchette edition was produced in $\mathrm{I}, \mathrm{OOO}$ numbered sets, bound in blue leather, gold-stamped on the spine and with facsimile signature gold-stamped on the front cover, top edges gold, $7^{1} / 8^{\prime \prime} \times 4^{1 / 2} 2^{\prime \prime}$. According to Flemingdon, Arthur Stringer was published in the library edition only, in I94I, and some copies have the imprint of the American co-publisher, BobbsMerrill of Indianapolis.

2 Both Duncan Campbell Scott and E.K. Brown found Pierce's literary judgement wanting at times. Their correspondence, collected in The Poet and the Critic, edited 
by Robert L. McDougall (Ottawa: Carleton University Press, I983) contains many references to Pierce, see for example pp. 53-54, and p. 66. A letter from Pierce to Brown, dated [1943?], in the E.K. Brown Papers at the Public Archives of Canada, Ottawa, reveals Pierce's many unsuccessful attempts to soften Brown's judgements in On Canadian Poetry, which Ryerson published in 1943.

3 Diary of Lorne Pierce, 9 August 1924 Lorne Pierce Papers; all further references to the diary will be made in the text.

4 The Lorne Pierce Medal is to be awarded annually if possible to 'citizens of Canada who shall have accomplished in imaginative or critical literature some achievement of special significance or conspicuous merit,' see Proceedings and Transactions of the Royal Society of Canada I9 (I925): xviii; for more on Pierce's contributions to Queen's University Library, see note 47.

5 Briggs' name had been used as an imprint on the trade publications of the Methodist Book and Publishing House between I879 and I918. Fallis devised the Ryerson imprint.

6 Lorne Pierce, ed., The Chronicle of a Century, 1829-1929 (Toronto: The United Church Publishing House, Ryerson, [1929]), p. 247.

7 See William Stewart Wallace, Foreword, The Ryerson Imprint (Toronto: Ryerson, [I954]), pp. 4-5.

8 Lorne Pierce, An Editor's Creed (Toronto: Ryerson, I960), p. 4.

9 See George L. Parker, "The Canadian Author and Publisher in the Twentieth Century,' in Editor, Author and Publisher, ed. William G. Howard (Toronto: University of Toronto Press, I968), p. 43.

ro See George Parker, 'A History of a Canadian Publishing House' (ph.D. diss., University of Toronto, I969), p. I 84.

I I John D. Logan to Lorne Pierce, I 8 September 1922, Lorne Pierce Papers; all further references to letters either to or from Pierce in this collection will be made in the text.

I2 Garvin formed his own company, the Radisson Society, to publish Master Works of Canadian Authors, which was intended to be a twenty-volume set reprinting the works of Canadian writers, with introductions, in a limited edition for subscribers at $\$$ Ioo a volume (Parker, 'History,' p. I 50). Only three volumes actually appeared: Paul Kane's Wanderings of an Artist among the Indians of North America (London, I859), in 1925; George Monro Grant's Ocean to Ocean: Sandford Fleming's Expedition through Canada in 1872 (Toronto, 1873), in I926; and Charles Mair's Tecumseh, A Drama, and Canadian Poems; Dreamland and Other Poems; The American Bison; Through the Mackenzie Basin; Memoirs and Reminiscences, which, although dated 1926, did not appear until April 1927, according to Norman Shrive, Charles Mair: Literary Nationalist (Toronto: University of Toronto Press, I965), p. 289.

I3 Shrive, Charles Mair, pp. 259-64.

I4 In fact, Pierce's doubt that John Logan, who worked slowly, would ever produce a completed volume on Haliburton in the Makers series may explain why Ryerson published Selections from Sam Slick, edited by Paul A.W. Wallace, in I923; see Parker, 'History,' pp. 271-72.

I 5 The definite titles were Robert Norwood, by Albert Durrant Watson; Thomas Chandler Haliburton, by John D. Logan; Isabella Valancy Crawford, by Katherine Hale; 'Charles Mair' by John Garvin; Peter McArthur by William Arthur Deacon; 'Robert Service,' by Arthur L. Phelps; William Kirby and John Richardson by 
William Renwick Riddell; and Gilbert Parker, by Garnet Gladwin Sedgewick. I6 Makers of Canadian Literature (Toronto: Ryerson, n.d.)

I7 B.K. Sandwell, review of the first six volumes of the Makers series, Canadian Historical Review 6 (March I925): 89.

I 8 [H.J. Davis?], 'Literary Criticism?' a review of the first six volumes of the Makers series, The Canadian Forum 4 (August I924), p. 344, refers to this as the first volume. Pierce sent a copy of Robert Norwood 'just fresh from the press' to Deacon on I May I923; Pierce to Deacon, William Arthur Deacon Papers, Thomas Fisher Rare Book Library, University of Toronto.

I9 Albert Durrant Watson, Robert Norwood, Makers of Canadian Literature (Toronto: Ryerson, I923), p. Io. Also in I923, Ryerson published Watson's Mediums and Mystics and a pamphlet by Pierce defending Watson's peculiar views: Albert Durrant Watson. Here shines the theosophical influence - Watson, although not a member, frequently attended and addressed meetings of the Toronto Theosophical Society. Several others connected with the Makers series were theosophically inclined, including Robert Norwood, William Arthur Deacon, and Katherine Hale; see Michèle Lacombe, 'Theosophy and the Canadian Idealist Tradition,' Journal of Canadian Studies 17, no. 2 (Summer 1982): 100-18.

20 'Literary Criticism?' p. 344.

2I Toronto Mail and Empire 26 May 1923, in Scrapbook Number Five, Lorne Pierce Papers.

22 William Renwick Riddell to Lorne Pierce, 23 January 1923, Pierce Papers; Alexander Clark Casselman, Biographical Introduction, Richardson's War of 1812, by John Richardson (I 842; reprint of the 1902 ed., Toronto: Coles, I974).

23 Perhaps because he realized that Riddell had not given his best, Pierce attempted to discover new biographical material on Kirby, and did, but too late for the Riddell volume. He comments in his introduction to William Kirby: The Portrait of a Tory Loyalist (Toronto: Macmillan, I929) p. xi: 'As Editor of this [the Makers] series, I was rather surprised to discover that, in view of Kirby's residence in Canada from I 839 to I906, so little new data could be gathered together, which might lend colour to his life and provide a more adequate context for his work.' Pierce finally managed to discover a huge trove of papers in the possession of Kirby's grandson, containing letters from princes, governors-general, assorted statesmen, poets, and writers, including Francis Parkman, Goldwin Smith, Catharine Parr Traill, and Alfred, Lord Tennyson, a discovery that resulted in two books Pierce published with Macmillan in 1929, William Kirby: The Portrait of a Tory Loyalist, and Alfred, Lord Tennyson and William Kirby.

24 Peter McArthur to Stephen Leacock, 25 May 1923, quoted by Alec Lucas, Peter McArthur (Boston: Twayne, 1975) p. 83.

25 Peter McArthur, Stephen Leacock, Makers of Canadian Literature (Toronto: Ryerson, I9231, p. I 59.

26 William T. Allison, 'You Scratch My Back,' review of the first five volumes of the Makers series, Calgary Herald, 22 February 1 924, in Scrapbook Number Five, Lorne Pierce Papers; Sandwell, review, p. 90.

27 David M. Legate, Stephen Leacock (Toronto: Macmillan, I970), p. I37.

28 'Literary Criticism?' p. 344.

29 Duncan Campbell Scott remarks in a letter to E.K. Brown, 8 February I943, that Pierce proposed a first run of Scott's edition of Lampman's poems of only 500 (McDougall, p. 54), a number that later rose to I,O0o (p. 64). 
30 Parker, 'History,' p. 275 ; in a note Parker says that the sales record book is unclear about a second printing, and it is possible that only $\mathrm{I}, 000$ copies in total were produced.

3I Clarence Heber Dickinson, Lorne Pierce: A Profile (Toronto: Ryerson, I965), p. 38; William Arthur Deacon to Anson B. Cutts, I4 March 1946, William Arthur Deacon Papers.

32 Marquis was the author of several historical novels and works of history as well as a chapter 'English-Canadian Literature' for the compendium history of Canada, Canada and Its Provinces, edited by Adam Shortt and Arthur G. Doughty (Toronto: Constable, I9I 3-I7).

33 E.E. Chevrier, M.P. introduced a bill to repeal the Licensing Clauses of the Copyright Bill of I923. The bill reached the Committee stage, and it is the Committee's discussions that Pierce appears to refer to. See the Bulletin of the Canadian Authors' Association, no. 4 (April r 925): 4-I I for more information on the Committee hearings.

34 Oxford University Press bought the plates from Morang and began revising and reissuing the series in 1926.

35 Toronto Globe, 17 May I924, Scrapbook Number Five, Lorne Pierce Papers; 'Literary Criticism?' p. 344.

36 Lorne Pierce to John D. Logan, 5 June 1924, Lorne Pierce Papers. Pierce sent Deacon a typewritten prospectus, 30 January I924, which listed Logan as the author of 'Joseph Howe,' Pierce as the author of 'Literary Backgrounds, The Lakes,' and A.A. (sic for G[arnet] G[ladwin]) Sedgewick as the author of 'Gilbert Parker'; this prospectus was earlier than Makers (see note I6).

37 See Toby Foshay, John D. Logan, Canadian Man of Letters: A Bio-Critical and Bibliographical Study with a Checklist of the Logan Papers in the Acadia University Library (Hantsport, N.s.: Published for the Acadia University Library, Lancelot Press, I982); John D. Logan to Lorne Pierce, 2 I January I924, Lorne Pierce Papers.

38 Toronto Globe, 4 July 1925; Saturday Night, 4 July 1925, both in Scrapbook Number Five, Lorne Pierce Papers.

39 Richard A. Davies, ed. \& intro., On Thomas Chandler Haliburton (Ottawa: Tecumseh, I979l, pp. 5-6.

40 John Ford MacDonald, William Henry Drummond, Makers of Canadian Literature (Toronto: Ryerson, [1925]), p. 92.

4I Dickinson, Lorne Pierce, pp. I-2.

42 Lorne Pierce to E.K. Brown, [I943?], E.K. Brown Papers, Public Archives of Canada, Ottawa, fol. 222.

43 [Lorne Pierce,] 'Biographical,' in Charles G.D. Roberts, Makers of Canadian Literature (Toronto: Ryerson, [I925]), p. 28.

44 William Arthur Deacon, review of Charles G.D. Roberts, by James Cappon, Saturday Night, I 3 June I925, p. 8.

45 I have seen undated copies of Stephen Leacock, and one dated I923, and the same for Robert Norwood.

46 Reginald Eyre Watters, A Checklist of Canadian Literature and Background Materials, 1628-1960, 2d ed., rev. \& enl. (Toronto: University of Toronto Press, I972).

47 H. Pearson Gundy's Letters of Bliss Carman (Kingston and Montreal: McGillQueen's University Press, I98I) is one important product of this collection. A catalogue of the Lorne Pierce Collection has been recently issued on microfiche 
(Kingston: Queen's University Archives, 1985). An earlier catalogue of the Canadian manuscripts, A Catalogue of Canadian Manuscripts Collected by Lorne Pierce and Presented to Queen's University, comp. Dorothy Harlowe; ed., rev. \& intro. E. Cockburn Kyte (Toronto: Ryerson, I 946), ran to I64 pages. For more information on Pierce's donations of books and papers to Queen's, see Clarence Heber Dickinson's Lorne Pierce: A Profile (Toronto: Ryerson, I965), especially p. viii, and pp. 53-56. Pierce was also important in the founding of the Bibliographical Society of Canada in May 1946.

Illustrations are courtesy of Queen's University Archives, Kingston, Ontario, Canada. 


\section{MaKeRs of}

\section{Canadian Literature}

From Haliburton. Garneau, and Richardson to Parker. Fréchette, and Carman

LORNE ALBERT PIERCE. Editor VICTOR MORIN, Associate Editor

(Fronch Soction)

Whit introdictions 8 s

RT. HON. SIR ROBERT LAIRD BORDEN.

P.C. G.C.M.G. UI.D.

SIR LOMER GOUIN.

X.C.M.G. U. D.

\section{ADYISORY $20.4 R D$}

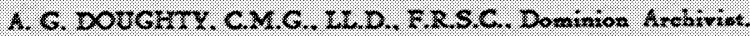
GzOrCE R. LOCXE, M.A. Chief Librarima. Toronto Public Iibrary.

W. J. KEALYY, Librarian. Provincial Zibrary, Manitoba.

IIS RONOUR, JUDCE F. W. ROWAY. F.R.S.C. Now Weotmainater, B.C.

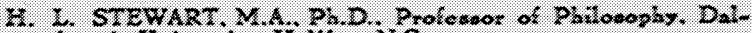
bounie Univernity. Halikax. NS.

\section{TORONTO THE RYERSON PRESS}

The first pages of the detailed prospectus (n.d.), probably issued to promote the Makers of Canadian Literature series to subscribers. 


\section{SPECIAL FEATURES}

The frst atternpt to give a complete account of the whiole feld of Canadian Literature, outstancing French writers of Canada being given the same prominence as the English writers.

Each volume consists of a full Biography, an Anthology of the "Maker's" representative work, a Critical Appreciation. an exhaustive Bibliography, and a carefally prepared Index. For the preparation of the volumes men of national reputation for literary insight have been secured.

Not only are the outstanding writers fully dealt with, but the Dictionary of Canadian Literature, the fnal volume. gives an account of every writer of importance from the frst setalement of Canada to the year 1924.

Every depariment of literature represented:

Oratory, Poetry, Fiction, Humour,

Belles Letires, eic.

A Colden Treasury of Canadian Literature. A Foundation Library of native literary criticism. An Encyclopadia of ready reference on every Canadian author. Handbooks for schools, colleges and literary clubs. A National Callery of literary portraits, both English and French.

\section{Valuable for Private Libraries and}

a Necessity for Public Libraries 